\title{
Factors affecting sporulation and infection of Peronospora sparsa in New Zealand boysenberry gardens
}

\author{
Anusara M. H. Mudiyanselage ${ }^{1}$, Hayley J. Ridgway ${ }^{1,2}$, Monika Walter ${ }^{3}$, Jason Smith ${ }^{4}$, Marlene V. Jaspers ${ }^{1}$ \\ and E. Eirian Jones ${ }^{1^{*}}$ \\ ${ }^{1}$ Department of Pest-management and Conservation, Lincoln University, Lincoln 7647, \\ Christchurch, New Zealand \\ ${ }^{2}$ The New Zealand Institute for Plant \& Food Research Limited, Lincoln 7608, New Zealand \\ ${ }^{3}$ The New Zealand Institute for Plant \& Food Research Limited, Motueka 7198, New Zealand \\ ${ }^{4}$ Horteye Ltd, 3 Bullen Street, Tahunanui, Nelson 7011, New Zealand
}

*Corresponding author: Eirian.Jones@lincoln.ac.nz

(Original submission received 27 October 2020; accepted in revised form 7 February 2021)

\begin{abstract}
Downy mildew, caused by Peronospora sparsa, is an economically important disease of boysenberries. Sporangia produced on infected tissue initiate berry infections; however the timing of sporangial release under New Zealand environmental conditions is unknown. The number of $P$. sparsa sporangia trapped on Vaseline ${ }^{\circledR}$-coated slides placed weekly in three boysenberry gardens in the Nelson region from October to December in 2010 and September to December in 2011 was determined. Climate data were used to determine environmental factors that promoted sporangia production/release. Incidence of dryberry symptoms and sporulation on tissue samples incubated at 15 or $20^{\circ} \mathrm{C}$ under high relative humidity (RH) were assessed. Peronospora sparsa sporangia were observed on slides from all three sites, with peak sporangial numbers in mid-November in both years. Sites with the highest numbers of sporangia trapped in November had higher dryberry incidence in December. Data indicated that sporangial release was triggered by percentage of rainy days, $\mathrm{RH}$ and warm temperatures $\left(16-23^{\circ} \mathrm{C}\right)$ in early spring, where high moisture periods promoted sporulation and a subsequent dry period allowed sporangial release. This study improves understanding of the timing of sporangial release to inform management practices.
\end{abstract}

Keywords dryberry, inoculum production, Peronospora rubi, Rubus sp., sporangia

\section{INTRODUCTION}

Downy mildew is one of the economically most important diseases of boysenberry worldwide with crop loss from the disease being up to $90 \%$ depending on the season (Kim et al. 2014). The disease is caused by the oomycete Peronospora sparsa (synonym P. rubi; Williamson et al. 1998) and is widespread in boysenberry (Rubus spp. hybrid) growing regions in New Zealand (Kim et al. 2014). The pathogen can result in systemic infection where lesions expand along the leaf veins, or as discrete spots on the leaf originating from spore-initiated infections (Tate 1981). The disease is also called 'dryberry' where early infection of green fruit results in premature reddening, shrivelling and rapid hardening of the fruit, i.e. dry berries, which also have a dull appearance (Gubler 1991). Peronospora sparsa is also a major pathogen of other Rubus species (e.g. raspberry (Rubus idaeus) and blackberry (Rubus fruticosus)) and also Rosa species including rose (Gubler 1991; Aegerter et al. 2002; Rodriguez-Diaz et al. 2017).
In New Zealand, leaf symptoms generally first appear on boysenberry plants in early spring, with sporangia predominantly produced on the abaxial surface of leaves in the lower part of the canopy due to the higher humidity levels present there (Tate 1981). This location makes early detection of the disease, and therefore control, difficult. The sporangia produced on infected tissues are disseminated by wind or free water initiating secondary infections on new leaves, flowers and fruit (Hall 1989; Gubler 1991; Hukkanen 2008). Gubler (1991) stated that, in general, downy mildew disease of raspberry, blackberry and hybrids (including boysenberry) was favoured by warm and wet weather in mid- to late-spring and also in autumn. However, the environmental factors that favour P. sparsa spore dissemination and subsequent disease development in boysenberry have not been well studied. For roses, the optimal temperatures for infection and colonisation of leaves by $P$. sparsa were reported to be 15 to $20^{\circ} \mathrm{C}$ and 20 to $25^{\circ} \mathrm{C}$, respectively, with infection requiring only $2 \mathrm{~h}$ of leaf 
wetness (Aegerter et al. 2003). That study also reported temperature to influence the latent period, that is, the time from infection to sporulation, with spore production occurring 4-5 days after infection at $15-25^{\circ} \mathrm{C}$ and after $7-8$ days at $10^{\circ} \mathrm{C}$. In contrast, Breese et al. (1994) reported greater sporulation by the pathogen at $10^{\circ} \mathrm{C}$ than at $20^{\circ} \mathrm{C}$ on tummelberry (blackberry $\times$ red raspberry). Additionally, although P. sparsa isolates from Rubus and Rosa hosts from both the UK and New Zealand were observed to have different temperature optima for spore germination, spores of all isolates were observed to germinate at temperatures of $2^{\circ} \mathrm{C}$ to $24^{\circ} \mathrm{C}$ (Breese et al. 1994). These authors also reported that disease incidence on tummelberry leaf discs inoculated with $P$. sparsa was highest at $15^{\circ} \mathrm{C}$, with infection occurring over a range from 2 to $28^{\circ} \mathrm{C}$. A disease-risk prediction model developed for P. sparsa by Kim et al. (2014) using data from New Zealand (boysenberry), the United States (rose) and Mexico (blackberry) indicated that high boysenberry downy mildew incidence occurred when the number of hours per day with temperature of $15-20^{\circ} \mathrm{C}$ averaged $>9.8$ over a month and coincided with rainfall occurring on $>38.7 \%$ of days in the month. However, the model developed by Kim et al. (2014) was based on disease incidence at harvest since detailed disease observation data such as sporangial spore counts and disease development in boysenberry gardens in New Zealand are limited. Identification of factors affecting the timing of sporangial dissemination and disease development in boysenberry gardens under New Zealand environmental conditions is, therefore, required for the development of effective control strategies including timing of fungicide applications.

The overall aim of this study was to determine the factors affecting the production and release of $P$. sparsa sporangia in boysenberry gardens. Spore trapping was conducted over 2 seasons (2010 and 2011) in three boysenberry gardens in the Nelson region, with dryberry infection incidence also evaluated in 2011. Climate data from the nearest weather station during the study period was obtained to attempt to determine the environmental factors promoting spore production or release.

\section{MATERIALS AND METHODS}

\section{Inoculum potential in the field}

\section{Timing of spore release in the field}

Spore traps were established in three boysenberry gardens in the wider Tasman area at the top of the South Island of New Zealand, at two grower properties in Motueka (Lower Moutere $(-41.174,172.975)$ and Upper Moutere (-41.236, 173.013)) and one grower property near Richmond $(-41.334,173.140)$. The Upper Moutere site used for spore trapping was surrounded by other boysenberry with some shelter and a small stream bordering the block. In contrast, the Lower Moutere site was a small block surrounded mostly by pasture and a few apple trees with little shelter, whilst the Richmond site was within a large area of boysenberry (approx. $40 \mathrm{ha}$ ) without any shelter belts between the blocks and being on the Waimea plains was relatively windy.
The Richmond site was planted on free draining river gravel soil, the Upper Moutere on silt soil and the Lower Moutere property a heavy clay soil. The spore traps were set up from October to December in 2010 and September to December in 2011. The boysenberry cultivars were 'Mapua' in Lower Moutere and Richmond, and 'Tasman' in Upper Moutere. The traps comprised of glass microscope slides coated with a thin layer of Vaseline ${ }^{\circledR}$. Coated slides were prepared by dissolving Vaseline ${ }^{\circledR}$ in hexane $(1: 7 \mathrm{w} / \mathrm{v})$ and using this solution to coat one side of each slide. Coated slides were allowed to dry in a fume hood. Coated slides were placed horizontally in boysenberry rows by clipping the slides onto strings using small bull-dog clips (Figure 1). There were five slides (2010) or four slides (2011) per property
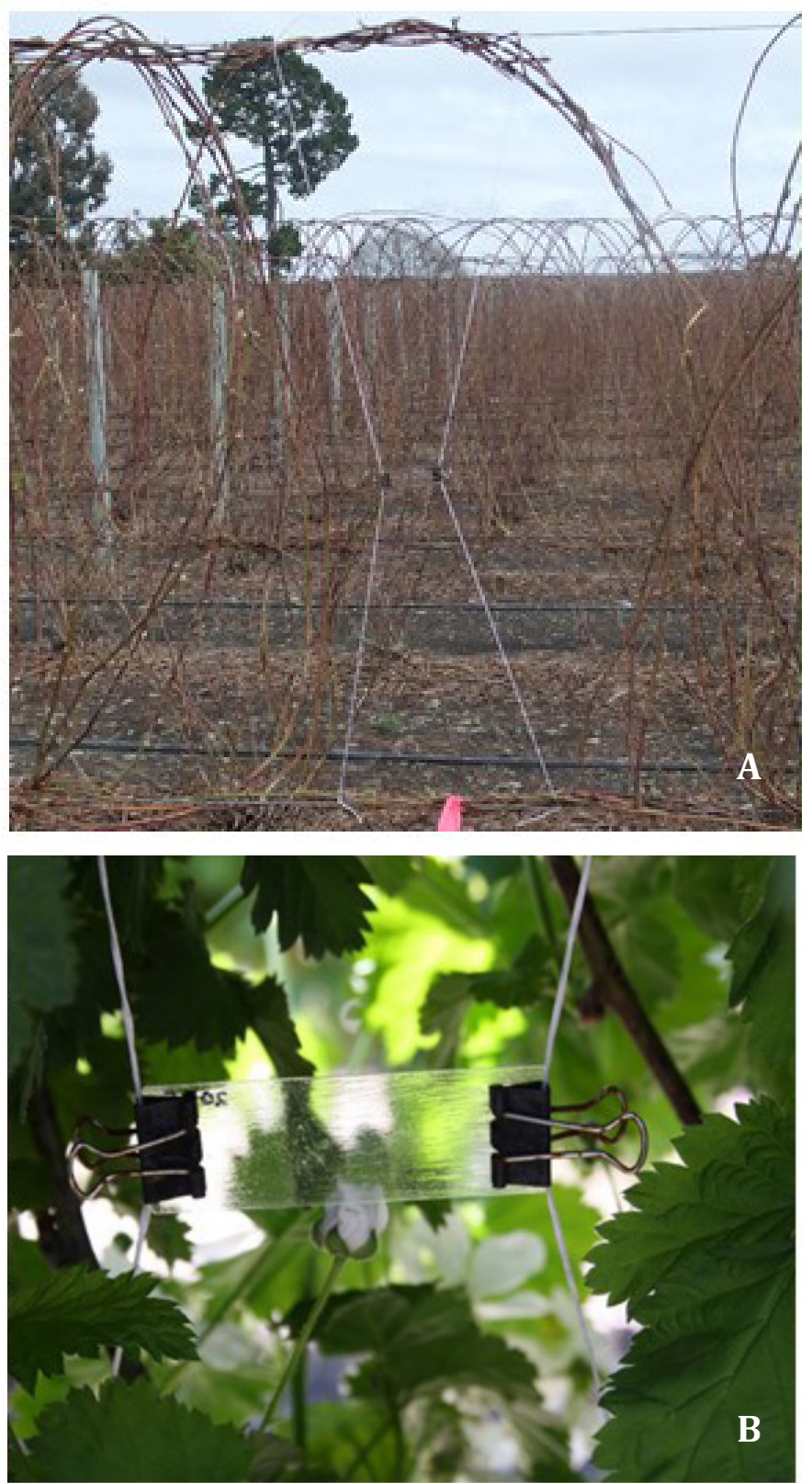

Figure 1 Vaseline ${ }^{\circledR}$-coated spore trap slides placed in the boysenberry canopy of field plants for trapping spores of Peronospora sparsa in 2011, shown in A) crop canopy in September, and B) the crop canopy in November. 
being replaced with new slides each week. The slides were placed in alternate bays within the selected row in each site. Each bay had three to five boysenberry plants depending on the site. The boysenberry rows were not sprayed with any chemicals during the period of the trials.

After collection each week, the deployed slides were brought back to the laboratory at Lincoln University for assessment. Each slide was divided into 12 vertical transects, which was the number of fields of view at $\times 10$ magnification across the slide. Two of these transects were selected using a random number table and examined using a bright field microscope at $\times 100$ magnification, with all of the sporangia characteristic of $P$. sparsa (Salgada-Salazar et al. 2018) counted. Sporangia of Peronospora sparsa are larger, (approx. $20 \times 15 \mu \mathrm{m}$ ) and ovoid in shape whereas conidia of Botrytis cinerea are smaller (approx. $12 \times 7 \mu \mathrm{m}$ ) and globose to ovoid in shape. The relative size of the spores was used to distinguish the P. sparsa sporangia since all the spores tended to collapse under the dry conditions on the slides and hence shape was harder to observe. These counts were used to determine the average number of sporangia per slide. For the 2011 assessment, confirmation of presence of $P$. sparsa sporangia on the slides at selected times from each of the three sites was carried out using species-specific nested PCR as described in Mudiyanselage et al. (2018). The four slides from each selected sampling time/site were washed together in a tube containing $10 \mathrm{~mL}$ sterile distilled water and held in a $60^{\circ} \mathrm{C}$ water bath for approximately $10 \mathrm{~min}$. The resulting suspension was centrifuged at 4696 $\times g$ for $10 \mathrm{~min}$, the supernatant discarded and the pellet used for DNA extraction using the modified CTAB method as described by Mudiyanselage et al. (2018). The nested PCR methods described by Mudiyanselage et al. (2018) were used to detect the presence of P. sparsa DNA. The nested PCR consisted of an initial PCR using the universal primers ITS5 (5'-GGAAGTAAAAGTCGTAACAAGG-3') and ITS4 (5'-TCCTCCGCTTATTGATATGC-3') (White et al. 1990) followed by a secondary PCR using $1 \mu \mathrm{L}$ of the primary PCR product as the template and the P. sparsa specific primers PR3 (5'-GGCTGGCTGCTACTGGGCA-3') and PR4 (5'-GCCGACTGGCCACGCGGA-3') (Lindqvist et al. 1998). The PCR amplification conditions were as follows: 3 min initial denaturing at $95^{\circ} \mathrm{C}$, followed by 35 cycles of $30 \mathrm{~s}$ at $95^{\circ} \mathrm{C}$, $30 \mathrm{~s}$ at $50^{\circ} \mathrm{C}$ and $45 \mathrm{~s}$ at $72^{\circ} \mathrm{C}$ with a final extension at $72^{\circ} \mathrm{C}$ for $10 \mathrm{~min}$. Ten $\mu \mathrm{L}$ of the secondary reaction was separated by electrophoresis in a 1.0\% agarose gel, stained with ethidium bromide and visualised with UV light. The presence of $P$. sparsa was confirmed by the presence of the expected band size (600 bp).

Weather data were obtained from the National Institute of Water and Atmospheric research (NIWA, New Zealand, http://cliflo.niwa.co.nz/pls/niwp/wgenf.genform1 proc) weather stations to determine environmental factors which promote sporangia production/release. Data from the two closest weather stations that provided all the four weather parameters i.e. wind speed, rainfall, relative humidity (RH) and temperature were used. The Riwaka Electronic Weather Station (Ews) was the closest weather station for both sites in Motueka - approximately $13.8 \mathrm{~km}$ from Lower Moutere site and $25.5 \mathrm{~km}$ from Upper Moutere site. The Nelson
Automatic Weather station (Aws) was approximately $14.8 \mathrm{~km}$ from the Richmond site.

Comparisons between the sporangia counts obtained in 2010 and 2011 for the same sites were made with respect to the sporulation potential across both years and with respect to weather conditions. In addition, the relationship with dryberry production in 2011 was also assessed.

The sporangia counts were $\log _{10}$ transformed following the addition of $1(\mathrm{x}+1)$ to account for zero values, to satisfy the assumption of homogeneity of variance, prior to analysis using the General Linear Model (GLM) in Minitab Ver.16. Site was considered as the random factor. When factors were significant, means were compared between treatments using Tukey's honest significant difference (HSD) at $P \leq 0.05$.

\section{Potential sources of inoculum under field conditions}

In the third week of November, 2011, leaf symptoms were assessed in the row where the spore traps were placed for each of the three sites. Five plants taken at random in each row were observed for leaf lesions on both the upper and lower leaf surfaces. Twelve symptomatic leaves were collected from both the Lower Moutere ('Mapua') and the Upper Moutere ('Tasman') sites. Floricane (12; 20-30 cm length), flower (10) and unripe green berry (24) samples from symptomatic plants were also collected from the Lower Moutere site. Plants were classified as being symptomatic if they had any leaves with characteristic downy mildew symptoms as the pathogen has been shown to be systemic in infected plants (Mudiyanselage 2015). Leaf symptoms included purple angular lesions due to systemic infections, and discrete spots as a result of spore initiated infections (Tate 1981). No symptoms were observed on the boysenberry plant material at the Richmond site so primocane (12; 20-30 cm length), flower (10) and unripe green berry (24) samples including calyces were collected from asymptomatic plants. All samples were transported using cold insulated boxes.

The symptomatic leaves from both the Lower Moutere and the Upper Moutere sites were placed separately in Petri dishes lids with the abaxial side of the leaf facing upwards. Six Petri dishes for each site were placed on racks in two separate plastic containers $(32 \mathrm{~cm} \times 26 \mathrm{~cm} \times 8 \mathrm{~cm})$ containing $\mathrm{H}_{2} \mathrm{O}(300 \mathrm{~mL})$ to produce $100 \% \mathrm{RH}$ and incubated at 15 or $20^{\circ} \mathrm{C}$ for 14 days to induce sporulation. The flowers were also placed separately in Petri dish lids and incubated at either 15 or $20^{\circ} \mathrm{C}$ in a $100 \%$ RH chamber as described. After 14 days, the leaves and flowers were observed under a stereo microscope to determine if sporulation had occurred.

Each floricane or primocane sample was cut aseptically into a 10 -cm segment. The bottom $2 \mathrm{~cm}$ of each cane segment was immersed in $10 \mathrm{~mL}$ sterile water in a sterile Universal bottle and each Universal bottle was sealed using Parafilm ${ }^{\circledR}$ (Bemis Inc., Oshkosh). The cane segments were then incubated in a humidity chamber consisting of a polystyrene tray within a new plastic bag. To provide $100 \%$ relative humidity, moistened paper towels were placed within the humidity chamber. The cane segments were incubated at $15^{\circ} \mathrm{C}$ and $20^{\circ} \mathrm{C}$ with six replicates per treatment. After 14 days, the canes were observed under a stereo microscope to determine if sporulation had occurred. 
For the berry samples collected from Lower Moutere, half were surface sterilised with $0.25 \%$ sodium hypochlorite solution for $30 \mathrm{~s}$ followed by a 5 min sterile water wash to reduce growth of Botrytis spp., whilst the other half were left unsterilised. The berries were bisected lengthwise, and the halves were placed separately cut surface down in a small (6 $\mathrm{cm}$ diameter) Petri dish lid, and incubated at either 15 or $20^{\circ} \mathrm{C}$ in a $100 \% \mathrm{RH}$ chamber as previously described. Six replicates were set up for each treatment. For the Richmond samples, the berries were all surface sterilised and incubated at either 15 or $20^{\circ} \mathrm{C}$ in a $100 \% \mathrm{RH}$ chamber as described. The berries were assessed after 14 days to determine if sporulation had occurred as described above.

\section{Disease assessment under field conditions}

The incidence of dry berries in the row where the spore trap slides were placed was determined for all three sites on the 23 and 29 December 2011. Berries with premature reddening, shrivelled and hard and having a dull appearance were considered as dry berries. The number of dry berries per bay was assessed from all plants and used to calculate the number of dry berries per plant. This procedure was conducted in all four bays where the spore trapping slides were located at each site. There were three to five plants per bay in the Lower Moutere site, whereas, there were five and four plants, respectively, in the Upper Moutere and Richmond sites.

\section{RESULTS}

\section{Inoculum potential in the field}

\section{Timing of sporangia release in the field}

Sporangia characteristic of $P$. sparsa were observed trapped on the Vaseline ${ }^{\circledR}$-coated slides (Figure 2) placed in the boysenberry rows in the three sites in both the 2010 and 2011 seasons. The nested PCR analysis using DNA extracts from the Vaseline ${ }^{\circledR}$-coated slides in the 2011 season confirmed the presence of $P$. sparsa sporangia.

In 2010, there was a significant $(P<0.0001)$ interaction between assessment time and site, which was associated with differences in the date when the largest numbers of

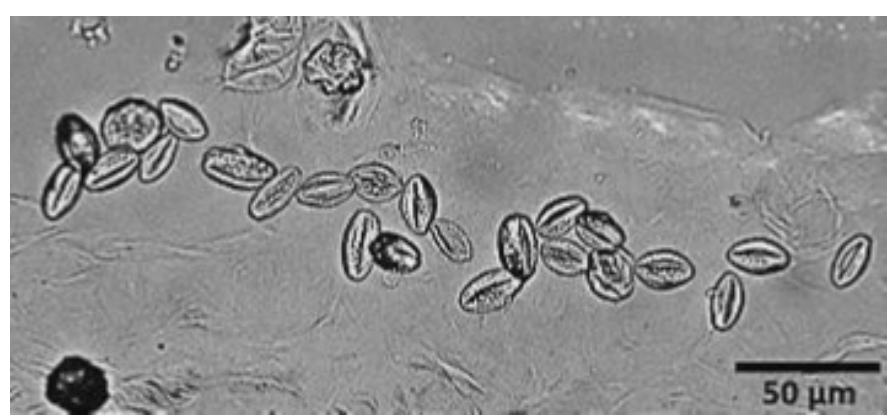

Figure 2 Hyaline and ovoid spores characteristic of Peronospora sparsa sporangia trapped on a Vaseline ${ }^{\circledR}$ coated slide placed in the canopy of boysenberry plants within a planting row at a site. Scale bar represents $50 \mu \mathrm{m}$. spores were trapped at the three sites. The highest number of sporangia trapped during 5-12 November were at the Richmond site (back-transformed mean 5012 sporangia), and during 12-19 November at the Upper Moutere site (back-transformed mean 6310 sporangia) (Table 1). There was a significant effect of time (date) $(P<0.0001)$ on the mean $\log _{10}$ sporangia counts, which was mainly associated with significantly higher mean sporangial counts for the two assessments in mid-November (5-12 and 12-19 November) compared with the majority of the other assessment times (Table 1). There was also a peak in sporangial numbers in early Oct (5-9 October) with the sporangial numbers not being significantly different to those in 5-12 November. There was no significant $(P=0.111)$ effect of site on the overall numbers of sporangia trapped.

In 2011, the interaction between assessment time and site was significant $(P<0.0001)$ and associated with differences in the date when the largest numbers of spores were trapped at the three sites. For all three sites, the highest number of spores were trapped during 5-12 November (backtransformed mean 40-126 sporangia) (Table 2). There was a significant effect of time (date) $(P=0.001)$ on the mean $\log _{10}$ sporangia counts, which was mainly associated with significantly higher mean spore counts for two assessments in November (5-12 and 12-19 November) and in late September - mid October (24 Sept - 8 October and 8-16 October) compared with the other assessment times. There was a significant effect of site $(P<0.0001)$ on the mean $\log _{10}$ sporangia counts, with significantly higher mean $\log _{10}$ sporangia counts in the Upper Moutere and Lower Moutere sites than from the Richmond site.

The total amount of rain recorded weekly in 2011 from both the Nelson Automatic Weather Station (nearest station to the Richmond site) and the Riwaka Electronic Weather Station (nearest station to the Upper and Lower Moutere site) was greater than that recorded in 2010 (Figures 3A and $4 \mathrm{~A}$ ). The total weekly rain pattern from September to December in 2010 was similar for both weather stations. A similar amount of rain was recorded for the two weather stations in 2011, apart from the 2-10 of December when approximately $300 \mathrm{~mm}$ was recorded from the Nelson weather station compared with only $100 \mathrm{~mm}$ from the Riwaka weather station.

According to the climate data obtained from the NIWA weather station, the percentage of days with rain in September 2010 was 55\% which was greater than the rain threshold ( $\mathrm{r} ; 38.7 \%$ ) determined by Kim et al. (2014). It was $26 \%$ and $23 \%$ in October and 23 and 13\% in November from the Nelson and Riwaka weather stations, respectively (Figure 5A). In contrast, in 2011 the percentage of days with rain in September recorded at both weather stations was always below the rain threshold value $(27 \%$ and $37 \%$ Nelson and Riwaka weather stations, respectively) although the percentage of days with rain for the next consecutive months reached or exceeded this value.

The mean weekly \% RH recorded in 2011 by the Riwaka weather station (70-95\%) fluctuated slightly more compared with that recorded in 2010 (70-85\%), but not for the Nelson weather station $(65-85 \%$ and $70-90 \%$, respectively for 2010 and 2011) (Figures 3B and 4B). However, in 2011 
Table 1 The numbers of spores $\left(\log _{10}\right)$ trapped on the Vaseline ${ }^{\circledR}$-coated glass slides per week over the trapping period October-December in 2010 at three sites in the Nelson region.

\begin{tabular}{|c|c|c|c|c|}
\hline Assessment period (Dates) & Spol & counts $\left(\log _{10}\right) \mathrm{pe}$ & site & \\
\hline & Lower Moutere & Upper Moutere & Richmond & Mean across all properties \\
\hline 5-9 Oct & 2.0 abcdefg $^{1}$ & 2.6 abcde & 1.3 cdefg & $2.0 \mathrm{BC}^{1}$ \\
\hline 9-15 Oct & $1.1 \mathrm{defg}$ & 1.6 cdefg & $0.3 \mathrm{fg}$ & $1.0 \mathrm{D}$ \\
\hline $15-23$ Oct & $0.6 \mathrm{fg}$ & 2.2 abcdef & $0.9 \mathrm{efg}$ & $1.2 \mathrm{CD}$ \\
\hline 23-29 Oct & $1.2 \mathrm{defg}$ & $0.4 \mathrm{fg}$ & 2.2 abcdef & $1.3 \mathrm{CD}$ \\
\hline 29-5 Nov & $1.1 \mathrm{defg}$ & $0.3 \mathrm{fg}$ & $3.2 \mathrm{abc}$ & 1.6 BCD \\
\hline 5-12 Nov & $3.0 \mathrm{abcd}$ & $0.7 \mathrm{efg}$ & $3.7 \mathrm{ab}$ & $2.5 \mathrm{AB}$ \\
\hline 12-19 Nov & $3.1 \mathrm{abcd}$ & $3.8 \mathrm{a}$ & $3.0 \mathrm{abcd}$ & $3.3 \mathrm{~A}$ \\
\hline 19-25 Nov & $0.8 \mathrm{efg}$ & $1.8 \mathrm{bcdefg}$ & 1.8 abcdefg & $1.4 \mathrm{CD}$ \\
\hline 25-2 Dec & $0.3 \mathrm{fg}$ & 2.2 abcdef & $0.7 \mathrm{efg}$ & $1.1 \mathrm{CDE}$ \\
\hline 2-9 Dec & $0.8 \mathrm{efg}$ & $0.9 \mathrm{efg}$ & $0.8 \mathrm{efg}$ & $0.8 \mathrm{DE}$ \\
\hline 9-16 Dec & $0.3 \mathrm{fg}$ & $0.3 \mathrm{fg}$ & $0.0 \mathrm{~g}$ & $0.2 \mathrm{E}$ \\
\hline Site effect & 1.3 & 1.5 & 1.6 & \\
\hline
\end{tabular}

${ }^{1}$ Values within the rows and columns followed by the same letter are not significantly different according to Tukey's test $(P \leq 0.05)$. The main effect of the assessment date $(\mathrm{A}-\mathrm{E})$ and interaction between the assessment date and site $(\mathrm{a}-\mathrm{g})$ was significant $(P<0.0001)$. The main effect of site was not significant $(P=0.111)$.

whilst the \% RH recorded by the Riwaka station was always above $90 \%$ during September to October, the level recorded by the Nelson weather station was generally lower in both years. The decrease in $\mathrm{RH}$ recorded over the period 5-25 November in 2011 at both weather stations corresponded with the greatest number of sporangia trapped. Further, the $\mathrm{RH}$ recorded at both weather stations during 25 November to 2 December and 2-10 of December was above $85 \%$, whilst in the previous year the RH was less than $80 \%$ during the same period. The sporangia numbers trapped during the same period were higher in 2010 compared with 2011 (Figures 3E and 4E).

The mean weekly maximum temperature (Tmax) recorded at both weather stations in 2010 fluctuated between $14-24^{\circ} \mathrm{C}$ (Figure 3C). In 2011, the Tmax recorded at both weather stations was between $16^{\circ} \mathrm{C}$ and $21^{\circ} \mathrm{C}$ with

Table 2 The number of spores $\left(\log _{10}\right)$ trapped on the Vaseline ${ }^{\circledR}$-coated glass slides per week over the trapping period September-December in 2011 at three sites in the Nelson region.

\begin{tabular}{lllll}
\hline Assessment period (Dates) & \multicolumn{3}{c}{ Spore counts $\left(\log _{\mathbf{1 0}}\right)$ per site } \\
\cline { 2 - 5 } 9-15 Sep & Lower Moutere & Upper Moutere & Richmond & Mean across all properties \\
\cline { 2 - 4 } 15-24 Sep & $0.2 \mathrm{~h}^{1}$ & $0.0 \mathrm{~h}$ & $0.0 \mathrm{~h}$ & $0.1 \mathrm{E}^{1}$ \\
$24-8$ Oct & $0.3 \mathrm{fgh}$ & $0.0 \mathrm{~h}$ & $0.0 \mathrm{~h}$ & $0.1 \mathrm{DE}$ \\
8-16 Oct & $1.5 \mathrm{abcde}$ & $1.5 \mathrm{abcdef}$ & $0.4 \mathrm{efgh}$ & $1.1 \mathrm{~B}$ \\
$16-22 \mathrm{Oct}$ & $0.7 \mathrm{bcdefgh}$ & $1.8 \mathrm{ab}$ & $0.5 \mathrm{efgh}$ & $1.0 \mathrm{~B}$ \\
$22-29 \mathrm{Oct}$ & $0.0 \mathrm{~h}$ & $0.6 \mathrm{bcdefgh}$ & $0.3 \mathrm{~h}$ & $0.4 \mathrm{CDE}$ \\
$29-5 \mathrm{Nov}$ & $0.3 \mathrm{gh}$ & $0.0 \mathrm{~h}$ & $0.0 \mathrm{~h}$ & $0.1 \mathrm{DE}$ \\
$5-12 \mathrm{Nov}$ & $0.9 \mathrm{bcdefgh}$ & $0.2 \mathrm{~h}$ & $1.4 \mathrm{abcdefg}$ & $0.8 \mathrm{BC}$ \\
$12-19 \mathrm{Nov}$ & $1.7 \mathrm{abc}$ & $2.1 \mathrm{a}$ & $1.6 \mathrm{abcd}$ & $1.8 \mathrm{~A}$ \\
$19-25 \mathrm{Nov}$ & $1.4 \mathrm{abcdefg}$ & $1.5 \mathrm{abcdef}$ & $0.7 \mathrm{bcdefgh}$ & $1.2 \mathrm{~B}$ \\
$25-2 \mathrm{Dec}$ & $0.5 \mathrm{cdefgh}$ & $1.1 \mathrm{abcdefgh}$ & $0.3 \mathrm{gh}$ & $0.6 \mathrm{BCD}$ \\
$2-10 \mathrm{Dec}$ & $0.5 \mathrm{efgh}$ & $0.5 \mathrm{defgh}$ & $0.0 \mathrm{~h}$ & $0.3 \mathrm{CDE}$ \\
$10-17 \mathrm{Dec}$ & $0.0 \mathrm{~h}$ & $0.0 \mathrm{~h}$ & $0.0 \mathrm{~h}$ & $0.0 \mathrm{E}$ \\
Site effect & $0.0 \mathrm{~h}$ & $0.0 \mathrm{~h}$ & $0.0 \mathrm{~h}$ & $0.0 \mathrm{E}$ \\
\hline
\end{tabular}

${ }^{1}$ Values followed by the same letter are not significantly different according to Tukey's test $(P \leq 0.05)$. The main effect of the assessment date (A-E) $(P<0.0001)$; site $(\mathrm{X}$ and $\mathrm{Y})(P=0.001)$ and interaction $(\mathrm{a}-\mathrm{h})(P<0.0001)$ between the assessment date and site were significant $(P<0.0001)$. 


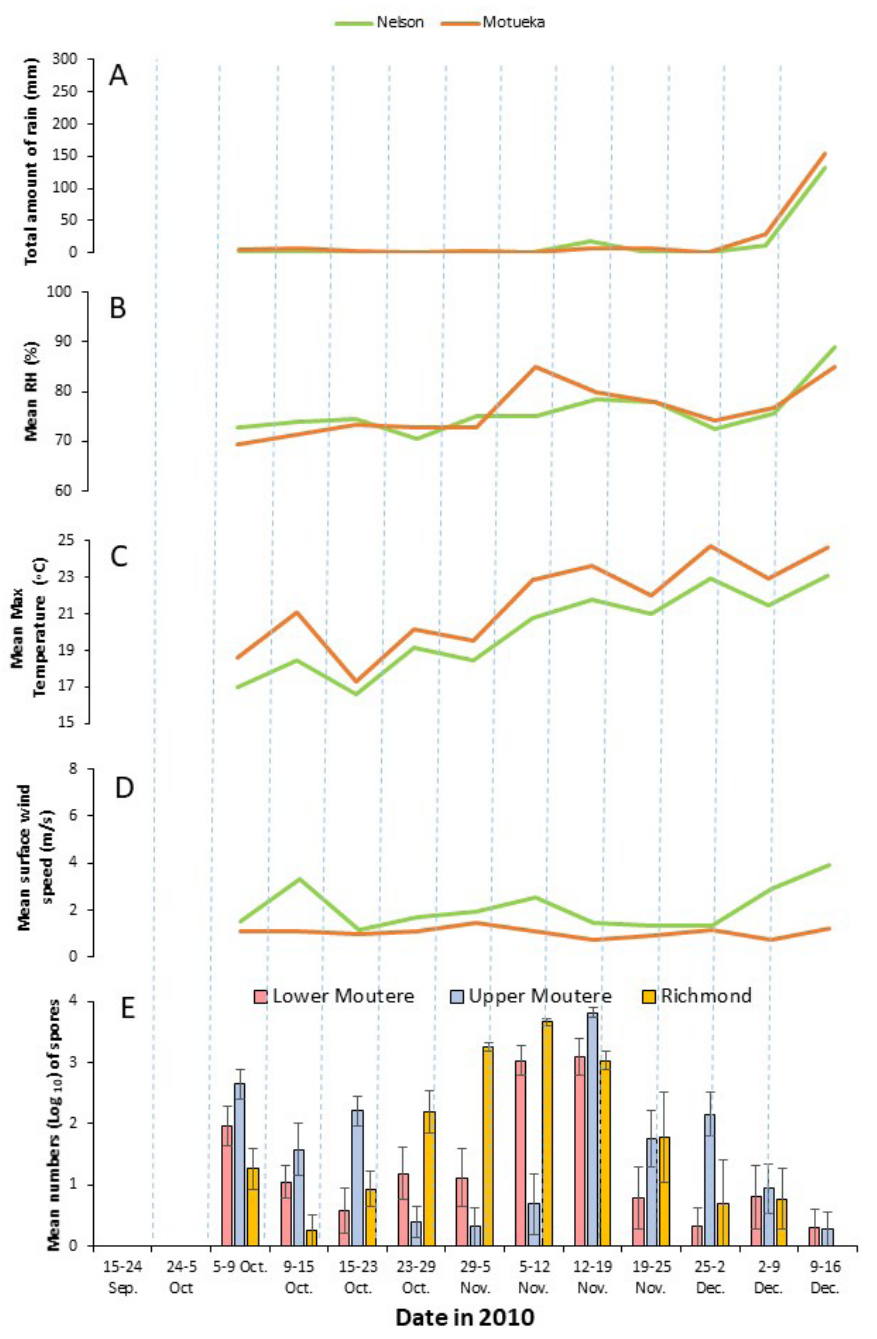

Figure $3(\mathrm{~A})$ Total amount of rain (mm), (B) mean RH (\%), (C) mean maximum temperature $\left({ }^{\circ} \mathrm{C}\right)$ and (D) mean surface wind speed $(\mathrm{m} / \mathrm{s})$ at $9.00 \mathrm{am}$, recorded during the weekly spore trapping periods in 2010 from the Nelson and Riwaka weather stations representing the weather conditions in the Richmond site and the two Motueka sites (Lower and Upper Moutere), respectively. (E) mean number $\left(\log _{10}\right)$ of spores characteristic of Peronosparsa sparsa trapped on Vaseline ${ }^{\circledR}{ }_{-}$ coated glass slides placed in three boysenberry sites, Lower Moutere, Upper Moutere and Richmond, at weekly intervals between October and December in 2010. Mean of four glass slides per site per week, with error bars representing the standard errors of weekly mean (SEM) spore numbers.

the pattern similar from both weather stations (Figure 4C). In 2010 and 2011, Tmax fluctuated between $18^{\circ} \mathrm{C}$ and $23^{\circ} \mathrm{C}$ at both weather stations during November when the number of sporangia trapped from all three sites were highest. During December (early summer) in 2010, the Tmax recorded at both weather stations was always above $20^{\circ} \mathrm{C}$. Sporangia were trapped on all dates at all sites apart from the 9-16 in December at the Richmond site. In contrast, in 2011, the mean Tmax recorded at both weather stations

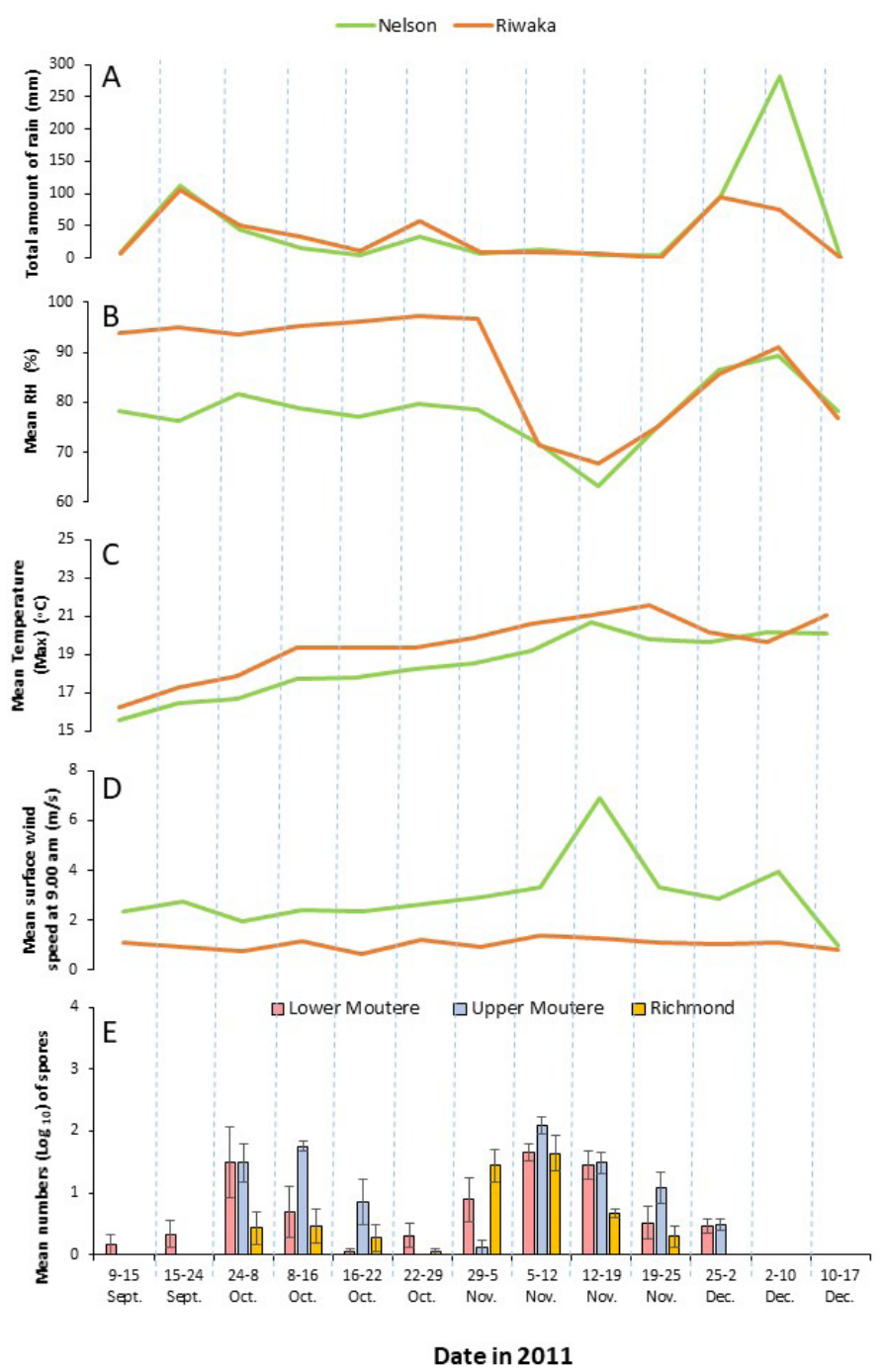

Figure 4 (A) Total amount of rain (mm), (B) mean RH (\%), (C) mean maximum temperature $\left({ }^{\circ} \mathrm{C}\right.$ ) and (D) mean surface wind speed $(\mathrm{m} / \mathrm{s})$ at $9.00 \mathrm{am}$, recorded during the weekly spore trapping periods in 2011 from the Nelson and Riwaka weather stations representing the weather conditions in the Richmond site and the two Motueka sites (Lower and Upper Moutere), respectively. (E) mean number $\left(\log _{10}\right)$ of spores characteristic of Peronospara sparsa trapped on Vaseline ${ }^{\circledR}-$ coated glass slides placed in three boysenberry sites, Lower Moutere, Upper Moutere and Richmond, at weekly intervals between September and December in 2011. Mean of four glass slides per site per week, with error bars representing the standard errors of weekly mean (SEM) spore numbers.

during December was always near $21^{\circ} \mathrm{C}$, with sporangia trapped only between 25 November and 2 December in the Upper and Lower Moutere sites with none trapped at the Richmond site.

According to the climate data obtained from the NIWA weather stations, the temperature threshold $(\mathrm{t} ; 9.8 \mathrm{~h})$ determined by Kim et al. (2014) as the average number of hours per day with temperature at $15-20^{\circ} \mathrm{C}$ was only exceeded in Nelson in November $(11.2 \mathrm{~h}$ and $10.0 \mathrm{~h})$ and 

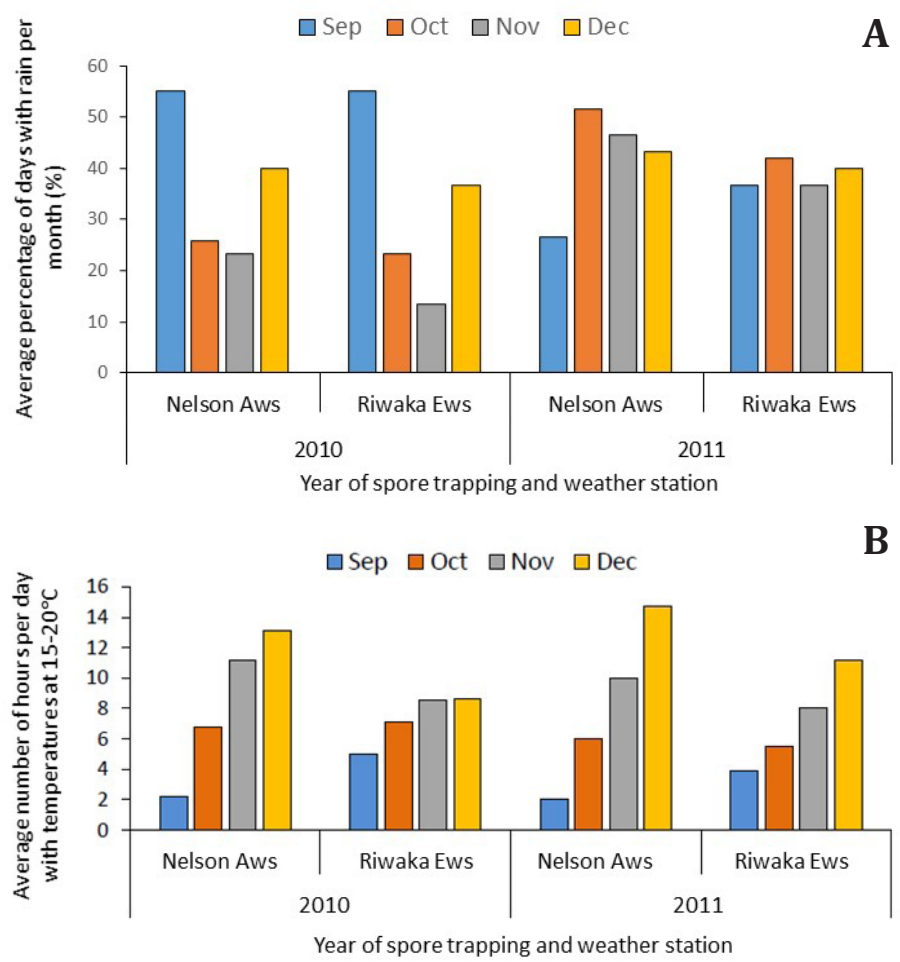

Figure 5 (A) The average percentage of days per month (Sept-Oct) with rain, and (B) the average number of hours per day with temperatures averaging $15-20^{\circ} \mathrm{C}$ per month (Sept-Dec) in 2010 and 2011during the spore-trapping experiment at the three sites based on the data from the Nelson automatic weather station (Aws) and the Riwaka electronic weather station (Ews).

December (13.1 h and $14.7 \mathrm{~h}$ ) in 2010 and 2011, respectively (Figure 5B). At Riwaka, the temperature threshold was only exceeded in December 2011 (11.2 h). The temperature threshold was not exceeded in any other month for either weather station.

The mean surface wind speed recorded at 9:00 am at the Nelson weather station in $2011(1-7 \mathrm{~m} / \mathrm{s})$ was greater than that recorded in 2010 (1-4 m/s) (Figures 3D and 4D). In 2010, the maximum mean wind speed of $4 \mathrm{~m} / \mathrm{s}$ was recorded during the 9-16 of December corresponding to no spores being trapped at the Richmond site. Whereas, in 2011 the mean maximum wind speed of $7 \mathrm{~m} / \mathrm{s}$ was recorded during the 12-19 of November which corresponded with the third highest number of spores $\left(0.7 \log _{10}\right.$ sporangia $)$ trapped during the year at the Richmond site (Figure 4E). In contrast, the mean surface wind speed recorded at the Riwaka weather station was relatively constant $(0-2 \mathrm{~m} / \mathrm{s})$ over the trapping period in both years.

\section{Potential sources of inoculum under field condition}

Symptomatic leaves were observed from the more shaded areas within the dense regions of the canopy at both the Lower Moutere and the Upper Moutere sites. More symptomatic leaves were observed on boysenberry plants in the Lower Moutere site than the Upper Moutere site; however sporulation on leaves was not observed in the field. No symptomatic leaves were observed from the assessed rows at the Richmond site. Only leaves obtained from the Lower Moutere site showed sporulation on the symptomatic lesions after incubation under the laboratory conditions used, with sporulation observed on $100 \%$ of the leaves incubated at $15^{\circ} \mathrm{C}$ and $83 \%$ at $20^{\circ} \mathrm{C}$ (both at $100 \%$ $\mathrm{RH})$. Leaves collected from the Upper Moutere site were found to be contaminated with the fungus Botrytis cinerea.

Sporulation was observed on the young floricane stems from the Lower Moutere site when incubated at $15^{\circ} \mathrm{C}$ and $100 \% \mathrm{RH}$ but not when incubated at $20^{\circ} \mathrm{C}$. No symptoms or sporulation was observed on asymptomatic primocanes or flowers.

Sporulation was observed on the calyces only of mature unripe fully expanded green berries collected from the Lower Moutere site when not surface sterilised with $0.25 \%$ sodium hypochlorite. Sporulation was observed on the calyces of all berries incubated at $15^{\circ} \mathrm{C}$ and $100 \% \mathrm{RH}$, whereas at $20^{\circ} \mathrm{C}$ and $100 \%$ RH sporulation only occurred on the calyces of $67 \%$ of berries. No sporulation or symptoms were observed on drupelets. No sporulation was observed on any of the berries (green unripe) collected from the Richmond site and incubated at 15 or $20^{\circ} \mathrm{C}$ at $100 \% \mathrm{RH}$ after surface sterilisation with $0.25 \%$ sodium hypochlorite.

\section{Disease assessment under field conditions}

There was a significant effect $(P<0.001)$ of site on the number of dryberries per plant in 2011, with more per plant at the Upper Moutere site. Also the mean number of dryberries per plant assessed on the $29 \operatorname{Dec}(P<0.001)$ was significantly higher than in the previous week (23 Dec) (Figure 6). The interaction effect of site and assessment time was highly significant $(P<0.001)$ with the most dryberries from the Upper Moutere site at the second assessment time (29 Dec).

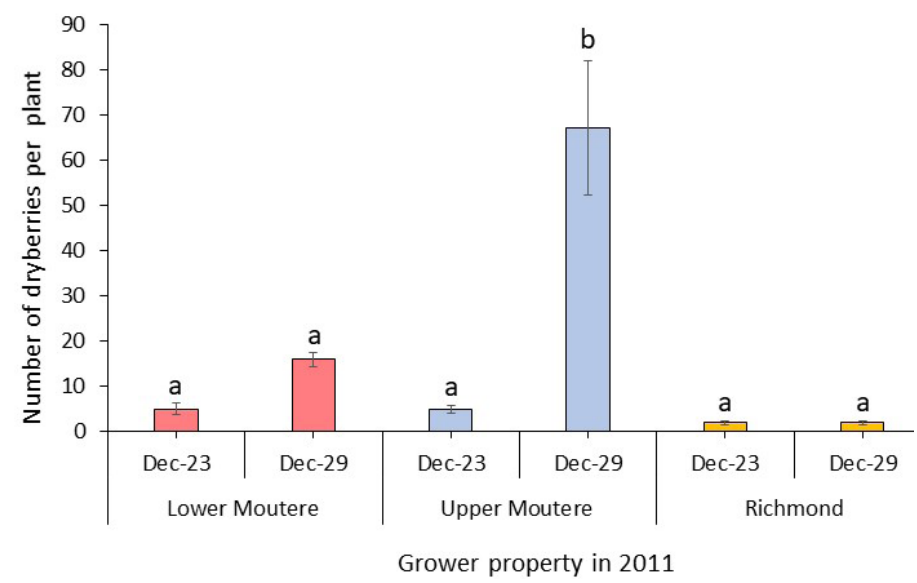

Figure 6 The mean numbers of dry berries per boysenberry plant in rows where the spore trapping slides were placed, assessed on the 23 and 29 December 2011, at three sites (Lower Moutere, Upper Moutere and Richmond). Bars with the same letters are not significantly different according to Tukey's HSD test $(P \leq 0.05)$. The main effect of site, assessment time and interactions are significantly different $(P<0.001)$. Error bars represent the standard errors of mean (SEM) number of dry berries per plant. 


\section{DISCUSSION}

This study is the first to investigate the release of sporangia in boysenberry gardens in New Zealand. Aerial sporangia were trapped in boysenberry gardens from early spring (September) to early summer (December), but there were differences in sporangial numbers over time. Weather data for the same time period indicated a relationship between rainfall pattern, humidity and temperature on the dispersal of sporangia in the field. The release of $P$. sparsa spores seemed to be related not to the amount of rain, but rather to the percentage of rainy days in early spring (September). This finding is consistent with those of Kim et al. (2014), who used temperature and rainfall data, along with disease incidence recorded over 11 years, to develop the 'Fuzzy Peronospora Sparsa' model to predict high disease risk periods. They identified the high disease risk seasons as those in which the number of days with rainfall was $>38.7 \%$ in any month. In the current study, the frequency of days with rain in September 2010 was greater than $38.7 \%$, although it was less than $26 \%$ for the next two months. However, it was during this dry period after September that most spores were trapped. This result suggested that the high percentage of rainy days promoted spore production but that subsequent spore release was less reliant on rain events. In 2011, data from the current study showed that the percentage of days with rain in September recorded at the Nelson weather station (close to Richmond site) was less than $38.7 \%$ (26.7\%), whereas the percentage was $36.7 \%$ at the Riwaka station (close to the Motuere sites). Thus, the difference in number of rainfall days in September is likely to be the reason for the difference in the dryberry disease level between the Upper Moutere (high incidence of dry berries on Dec 29) and Richmond sites. However, there may also be local environmental differences that affect spore release since the Lower Moutere site had an intermediate dryberry disease level.

Temperature is also reported to influence P. sparsa disease incidence in Rosa spp. and Rubus spp. (Gubler 1991, Aegerter et al. 2003; Salgada-Salazar et al. 2018). The temperature ranges for the 2010 and 2011 seasons were similar and, therefore, the lower number of spores trapped in 2011 indicate that spore release is influenced by a combination of environmental parameters rather than temperature alone. Kim et al. (2014) reported that risk of high incidence of this disease was associated with a combination of temperature and the number of rainfall days. If the mean number of hours per day of $15-20^{\circ} \mathrm{C}(\mathrm{t})$ was $\geq 9.8 \mathrm{~h}$ in a month and $\geq 38.7 \%$ of the days had some rainfall (r) then the disease risk would be high. In the current study, in 2011 both conditions were satisfied in November ( $\mathrm{t}=10$ and $\mathrm{r}=47 \%$ ) and December $(t=15$ and $r=43 \%)$ based on data from the Nelson weather station, and the conditions were only satisfied at the Riwaka weather station in December $(\mathrm{t}=11$ and $\mathrm{r}=40 \%)$. However, the greatest dryberry disease incidence was from the Upper Moutere site, which was associated with the Riwaka weather station and the Richmond (Nelson weather station) site had the lowest dryberry disease incidence. This finding suggested that dryberry disease incidence may be related to timing of the conducive conditions and to local differences in climatic factors (such as diurnal variation) in addition to the combination of $t$ and $r$. The observed differences in dryberry disease incidence may also reflect differences in grower management practices, such as crop hygiene practices, pesticide spray usage, cane training, and relative amount of shelter as well as the surrounding vegetation. Differences in the environmental conditions recorded at the weather stations and those actually experienced at the sites might also have resulted in errors with interpreting the effect of environmental factors on spore counts. Although all three sites are located in the Tasman region, local variations in environmental conditions among sites, and also within site, are likely to influence not only spore production and release but also spore infection and hence disease incidence.

Relative humidity (RH) during early spring also affected spore release. In 2010, a wet September was followed by relatively low rainfall during October and November and the $\mathrm{RH}$ fluctuated between $70 \%$ and $85 \%$ during the latter two months (National Institute of Water and Atmospheric research, New Zealand). In contrast, there was greater frequency of rainfall during October to December in 2011 , and the $\mathrm{RH}$ fluctuated over a wider range $65 \%$ to $95 \%$ ). However, the means were calculated for the period of time (4-5 days) that the slides were in the field, with the environmental conditions likely to fluctuate not only within that period but also within a day. Therefore, a dry period $(1 \mathrm{~h})$ within this period was likely to facilitate sporangial dispersal from sporangiophores. This hypothesis is consistent with the known biology of spore release for oomycetes. The hygroscopic twisting of Phytophthora infestans and Peronospora tabacina sporangiophores as a result of changes in $\mathrm{RH}$ has been reported to enhance spore dispersal through the dry, active mechanisms of spore dispersal common in oomycetes (Lacey 1996). In addition, a study conducted on Pseudoperonospora cubensis, the causative agent of downy mildew in cucurbits, reported that sporangiophores twist as they desiccate, resulting in the sporangia detaching so they are easily dispersed by the air currents (Erhardt 2009). The greater number of sporangia trapped in November 2010 than in November 2011 may have been associated with the wetter September in 2010 (data not shown). Erhardt (2009) reported that the mechanism by which sporangia are released from sporangiophores is facilitated by an early wet period where high moisture levels promote spore production with a subsequent dry period facilitating sporangial dispersal.

Wind speed did not appear to affect Peronospora sparsa sporangial release. The wind speed detected by the Nelson weather station was greater in 2011 than 2010; however there were more sporangia trapped in 2010. Further, the wind speed detected at the Nelson weather station site fluctuated in both years whereas it was generally consistent at the Riwaka weather station site. Wind speed was not considered by Kim et al. (2014) to be an environmental variable that influenced disease incidence. In contrast, wind speed was reported to affect release of Ph. infestans spore from the potato canopy, with higher wind speed correlating to more spores for the same moisture conditions (Harrison \& Lowe 1989). Even moderate winds were reported to be effective at dispersing Peronospora tabacina spores upwards from the bottom of the canopy of tobacco (Nicotiana 
tabacum L.) (Aylor 1990). In the current study, only the surface wind speed was considered, with wind direction not determined. The direction of the wind at the study sites may have varied during the assessment period and may have reduced sporangia impacting on the Vaseline ${ }^{\circledR}$-coated slides in some months, resulting in inconsistent data. Further work is required to determine the effect of wind speed and direction on sporangia release and, therefore, disease incidence in the field.

For the Upper Moutere site, the high number of sporangia trapped during 2011 corresponded to higher dryberry incidence in December. In contrast, low dryberry disease at the Richmond site corresponded with low sporangia numbers at this site. Similarly, more leaf lesions were observed in the boysenberry gardens at the Upper and Lower Moutere sites than the Richmond site in November, 2011. However, much lower dryberry incidence was recorded at the Lower Moutere site although the prediction based on the weather data and the sporangia numbers recorded was similar to that for Upper Moutere. In addition to the environmental conditions, differences in the susceptibility of the boysenberry cultivars grown at the different sites may have also influenced disease incidence. The cultivar grown at the Lower Moutere and the Richmond sites was 'Mapua', whilst 'Tasman' was grown at the Upper Moutere site. In vitro studies however showed there was no difference in the relative susceptibility of these two cultivars to $P$. sparsa infection although both the incidence and sporulation was slightly higher on inoculated 'Tasman' leaf discs compared with 'Mapua' (Mudiyanselage 2015) and whether this would result in higher disease levels under field conditions needs further investigation.

The selection of the temperatures used in the study to incubate the boysenberry plant tissue samples was based on the results of Breese et al. (1994) who showed that sporulation occurred on $P$. sparsa inoculated tummelberry (blackberry and red raspberry hybrid) leaf discs incubated at $2-28^{\circ} \mathrm{C}$, with maximum numbers of leaf discs that produced spores occurring at $14.7^{\circ} \mathrm{C}$. The results of this study are in agreement with maximum sporulation of $P$. sparsa on boysenberry leaves observed at $15^{\circ} \mathrm{C}$ at $100 \% \mathrm{RH}$ compared with at $20^{\circ} \mathrm{C}$.

In conclusion, the sporangia trapping method allowed for assessment of sporangia release timing and hence the risk period of $P$. sparsa infection in boysenberry gardens under New Zealand conditions. The disease was initiated by rain in early spring, which promoted sporulation with sporangia release and dispersal - possibly being triggered by subsequent dryer periods occurring in mid to late spring and infection of the host tissue in late spring-early summer. This information has substantial implications for diseasemanagement decisions primarily with regards to the timing of fungicide applications in the field to protect boysenberry tissue from sporangia infection. Sporulation from naturally infected leaves, stems/canes and calyces under optimum conditions of $15^{\circ} \mathrm{C}$ and high humidity were identified as providing for potential inoculum in the field. However, sporulation was not observed on either flowers or berries. Berry infections resulting in dryberry disease causes major yield losses for the grower and whether this situation results from direct sporangia infection or systemic growth of the pathogen into the developing flower and/or berry tissue is not known and warrants further study.

\section{ACKNOWLEDGEMENTS}

The authors are grateful to the Boysenberry Council Ltd, Technology for Industry Funding (Callaghan Innovation) and the New Zealand Ministry of Science and Innovation for providing a scholarship to the first author, and the Boysenberry Council Ltd and Lincoln University for funding. We thank the boysenberry growers for allowing us to conduct the research in their gardens, and Mr Julian Raine (Boysenberry Council Ltd) who gave valuable support.

\section{REFERENCES}

Aegerter BJ, Nuñez JJ, Davis RM 2002. Detection and management of downy mildew in rose rootstock. Plant Disease 86(12): 1363-1368. https://doi.org/10.1094/ PDIS.2002.86.12.1363

Aegerter BJ, Nuñez JJ, Davis RM 2003. Environmental factors affecting rose downy mildew and development of a forecasting model for a nursery production system. Plant Disease 87(6): 732-738. https://doi.org/10.1094/ PDIS.2003.87.6.732

Aylor DE 1990. The role of intermittent wind in the dispersal of fungal pathogens. Annual Review of Phytopathology 28: 73-92. https://doi.org/10.1146/ annurev.py.28.090190.000445

Breese WA, Shattock RC, Williamson B, Hackett C 1994. In vitro spore germination and infection of cultivars of Rubus and Rosa by downy mildews from both hosts. Annals of Applied Biology 125(1): 73-85. https://doi. org/10.1111/j.1744-7348.1994.tb04948.x

Erhardt CJ 2009. Developing a high-throughput, SNP-based population screening method for Pseudoperonospora cubensi. Unpublished $\mathrm{PhD}$ Thesis, Michigan State University, USA.

Gubler WD 1991. Downy mildew. In: Ellis MA, Converse RH, Williams RN, Williamson B Eds. Compendium of raspberry and blackberry diseases and insects (Second edition). The American Phytopathological Society, St. Paul, MI, USA (APS Press). Pp. 15-16.

Hall G. 1989. Unusual or interesting records of plant pathogenic oomycetes. Plant Pathology 38(4): 604-611. https://doi.org/10.1111/j.1365-3059.1989.tb01458.x

Harrison JG, Lowe R 1989. Effects of humidity and air speed on sporulation of Phytophthora infestans on potato leaves. Plant Pathology 38: 585-591. https://doi. org/10.1111/j.1365-3059.1989.tb01455.x

Hukkanen A 2008. Chemically induced resistance in strawberry (Fragaria $\times$ ananassa) and Arctic bramble (Rubus arcticus) biochemical responses and efficacy against powdery mildew and downy mildew diseases. Unpublished PhD Dissertation, Kuopio University, Finland.

Kim KS, Beresford RM, Walter M 2014. Development of a disease risk prediction model for downy mildew (Peronospora sparsa) in boysenberry. Phytopathology 104(1): 50-56. https://doi.org/10.1094/PHYTO-02-13-0058-R 
Lacey J 1996. Spore dispersal - its role in ecology and disease: the British contribution to fungal aerobiology. Mycological Research 100(6): 641-660. https://doi. org/10.1016/S0953-7562(96)80194-8

Lindqvist H, Koponen H, Valkonen JPT 1998. Peronospora sparsa on cultivated Rubus arcticus and its detection by PCR based on ITS sequences. Plant Disease 82(12): 3041311. https://doi.org/10.1094/PDIS.1998.82.12.1304

Mudiyanselage AMH 2015. Peronospora sparsa biology and drivers of disease epidemics in boysenberry. PhD Thesis, Lincoln University, New Zealand. https://researcharchive. lincoln.ac.nz/bitstream/handle/10182/6720/Herath PhD. pdf

Mudiyanselage AMH, Ridgway HJ, Walter M, Jaspers MV, EE Jones 2018. Heat and fungicide treatments reduce Peronospora sparsa systemic infection in boysenberry tissue culture. European Journal of Plant Pathology 153(2): 1-6. https://doi.org/10.1007/s10658-018-1564-y

Rodríguez-Díaz KJ, Silva-Rojas HV, Boyzo-Marin J, SeguraLedesma SD, Leyva-Mir SG, Rebollar-Alviter Á 2017. Molecular detection of Peronospora sparsa in sources of primary inoculum and components of resistance in wild blackberry species. European Journal of Plant Pathology 149(4): 845-851. https://doi.org/10.1007/s10658-017$1232-7$

Salgada-Salazar C, Shishkoff N, Daughtrey M, Palmer CL, Crouch JA 2018. Downy mildew: A serious disease threat to rose health worldwide. Plant Disease 102: 1873-1882. https://doi.org/10.1094/PDIS-12-17-1968-FE

Tate KG 1981. Aetiology of dryberry disease of boysenberry in New Zealand. New Zealand Journal of Experimental Agriculture 9(3-4): 371-376. https://doi.org/10.1080/0301 $\underline{5521.1981 .10425436}$

Williamson B, Cooke DEL, Duncan JM, Leifert C, Breese WA, Shattock RC 1998. Fungal infections of micropropagated plants at weaning: a problem exemplified by downy mildews in Rubus and Rosa. Plant Cell, Tissue and Organ Culture 52(1-2): 89-96. https://doi. org/10.1023/A:1005909704951

White TJ, Bruns TLS, Taylor J 1990. Amplification and direct sequencing of fungal ribosomal RNA genes for phylogenetics. Academic Press, San Diego, CA, USA. https://doi.org/10.1016/B978-0-12-372180-8.50042-1 